\title{
超高真空仕様表面波励起高密度 プラズマ発生装置の評価*
}

\author{
伴 野 達 也*1 \\ （受理2003年11月 14 日，掲載決定2004年 2 月 14 日） \\ UHV-Compatible Apparatus for the High-Density \\ Plasma Induced by Surface Wave Modes \\ Tatsuya BANNO*1 \\ ${ }^{*}$ Department of Applied Physics, University of Tokyo \\ Hongo 7-3-1, Bunkyo-ku J-113-8656 Tokyo, Japan \\ (Received November 14, 2003, Accepted February 14, 2004)
}

\begin{abstract}
A microwave launcher with a ring slot has been designed, allowing a UHV viewing port to be utilized as a dielectric material in order to induce high-density plasma with the surface wave mode in a UHV compatible chamber. Electrostatic probe measurements on the plasma show that the plasma density distribution results from an intensive ionization rate in the vicinity of the dielectric/plasma interface and from the ambipolar diffusion. When nitrogen is mixed to argon gas, the plasma density remains almost constant as a result of the descrete surface mode, whereas the atomic nitrogen density varies in proportion to the nitrogen partial pressure.
\end{abstract}

\section{1. はじめに}

マイクロ波が誘電体を介してプラズマと相互作用する 際に，表面波モードとなり，カットオフ密度を超える高 密度プラズマが発生することがよく研究されてきてい $ろ^{1)}$. 定常外部磁場が不要で, 容易に大面積化も行なえ て, 高プラズマ密度はイオンのみならずラジカル密度も 高いであろうから，例えば高速プロセッシングに応用で きると期待される. 一方プロセシングの高清浄化の必要 性が唱えられており，とりわけ磁性体薄膜の記憶媒体応 用のためには, 酸化層の形成に関して放電容器の酸素分 圧・酸素原子密度の制御が必要であることが報告され た ${ }^{2)} \cdot 10^{-7} \mathrm{~Pa}$ 相当の酸素ガスを有意に制御するには, 到達圧を $10^{-8} \mathrm{~Pa}$ 以下にすることが必要であろうし，そ のためには充分に脱ガスできる材質のみで組み上げた放

\footnotetext{
* 平成15年11月14日 第44回真空に関する連合講演会にて発表

*1 東京大学大学院工学系研究科物理工学専攻 (T113-8656 文京区本郷 $7-3-1$ )
}

電容器を用いる必要がある. 表面波プラズマの実験装置 はマイクロ波の導入部に石英等の誘電体を真空封じにも 兼用していることが多く, Oーリングをエラストマーと して用いているので，こういった極高真空には対応して いない.そこで最大口径を持った市販のパイレクスガラ ス製ヴューポートフランジをマイクロ波導入部に利用で きないかを検討することにした。

次に $2.45 \mathrm{GHz}$ のマイクロ波にとってはカットオフ密 度を越えるような高密度の無電極放電プラズマをプロー ブ計測する際に，たとえば電子電流を飽和領域で引き出 すことは，正味に大きな電流をプラズマから引き出すこ とになる.プローブが引き出した分の電流を, 直流的に は絶縁体であるパイレクスガラス等の誘電体に接してい るプラズマに定常的に補う機構があるとは思えない．本 質的には測定系が浮遊しているダブルプローブが採用さ れるべきであるが，ダブルプローブは電子エネルギー分 布関数を算出する目的の手段ではないし，よく知られて いるように原理的にもっぱら電子エネルギー分布関数の 
高エネルギー尾部の情報に影響されやすいとされてい る $^{3)}$. ここでは極めて面積の小さい円筒電極とその約 100倍の面積をもつ円板電極とを用いて非対称ダブルプ ローブとして採用することにし，実質的に後者を参照電 極, 円筒電極を単短針とみなして解析できるかどうかを 検討することにした.

マイクロ波がプラズマと結合する際に表面波モードが 発生することが高密度プラズマを維持するために必要条 件であるが，逆に表面波電場があればなぜ高密度プラズ マとなるか明確ではない. 発光強度の目視観察でもプラ ズマの誘電体との界面付近が最も強く発光しているた め, プラズマ密度も界面付近が最大になっていると思わ れがちだが，これを古典的な両極性拡散モデルで解析す ること試みてみる。

\section{2. 実験}

表面波プラズマを発生させるためには，マイクロ波導 波管の底板に切り込みを設け，それを一種の方向性結合 器のスロットと見立てたランチャーが一般的に使用され ている.しかし本研究で用いることにした広視野角のい わゆるゼロレングス仕様のヴューポート（ICF203：アー ルデック社 ZPV-600）はフランジを固定するためのネ ジ頭がフランジ面よりも外に出るため, このスロットと パイレクスガラス面を密着することはできず, $12 \mathrm{~mm}$ 程度の隙間が生じ，マイクロ波の電力損失の原因になり える. またガラス面の直径の方が規格の WRJ-2 導波管 の幅よりも長く, 反射マイクロ波の漏れが懸念される し, スロット部付近以外のガラス面が電力の伝達に関係 しないのなら，大きな面積のパイレクスガラスが有効に 利用できるているとは言えない，そこでテーパー管を製 作して導波管の幅を広くして, 岡本キャビティと呼ばれ るリングスロット方式(4)のランチャーに接合し，そのリ ングスロットとガラス面との間には中心部分のない同軸 円筒状の短管をキャビティと一体で製作して取り付け た. Fig. 1 に放電容器とマイクロ波ランチャーの付近の 模式的断面図を示す. 放電容器はステンレス鋼製で, 内 径 $18 \mathrm{~cm}$ 長さ $35 \mathrm{~cm}$ の円筒状真空容器であり, $400^{\circ} \mathrm{C} の$ ベーキングが可能である.

$10^{-6} \mathrm{~Pa}$ までターボ分子ポンプで排気した後, アルゴ ンおよび窒素ガスを独立の導入系から 0 から $10 \mathrm{sccm}$ 程 度で定常的に導入し，主排気バルブを全閉し，全圧が $100 \mathrm{~Pa}$ になったところで $300 \mathrm{~W}$ 程度のマイクロ波を供 給し，放電が開始した後に全圧をたとえば $5 \mathrm{~Pa}$ に維持 するように主排気バルブを開いた.

非対称ダブルプローブの電極部はタンタル製であり， 2 組用意し, それぞれ直線導入器に取り付けられて, 放

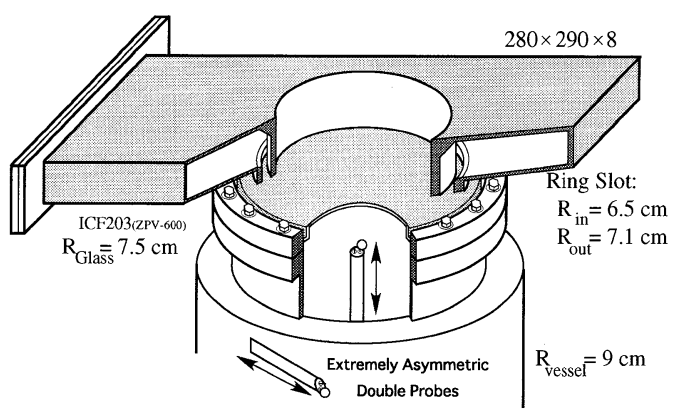

Fig. 1 Schematic description of a part of the experimental apparatus.

電容器の円筒中心軸方向 ( $\mathrm{z}$ 軸方向) と半径方向 $(\mathrm{r}$ 方 向, $z=10 \mathrm{~cm}$ 固定) に移動できる. 電極間には Keithley 社製ソースメジャーユニット KE236 と結線してバ イアス電圧（ー20から+20 V 程度）をかけた。データ 解析に際しては, 微小面積の電極を単短針とみなして, 測定した電流電圧特性からプラズマパラメータと電子エ ネルギー分布関数をそれぞれ空間座標の関数として求め ることにした．

プラズマ中の生成粒子の計測手段としては発光分光計 測法と，円筒壁の位置に置いたミニチュア質量分析計5) を用いた。

\section{3. 結果および考察}

放電開始した圧力においては目視観察で，このパイレ クスガラスの内側に表面波モードを特徴づける 6 回対称 の発光パターンが見られた．設定圧力まで下げると平均 自由行程が長くなり, 一様な発光パターンに変化した.

Fig. 2 にはプローブ計測結果の一例として窒素ガスの み6.6 Pa，マイクロ波出力 $400 \mathrm{~W}$ で得られた電子密度の 空間分布を示した. 軸方向にはパイレクスガラスのプラ ズマ側の端面 $(\mathrm{z}=0)$ から $\mathrm{z}=3 \mathrm{~cm}$ の位置に最大密度が 得られている. 密度がカットオフ密度を越えていないの で, 完全な表面波モードではなく, ハイブリッド表面波 モード1)になっている. 半径方向の一様性は容器円筒半 径が小さいために, 壁の影響が出ていると思われ, 0 次 のベッセル関数的である.

プローブ計測から求められたエネルギー分布関数 $f(E)$ に基づいてイオン生成レートQを

$$
Q=\int n_{\mathrm{g}} n_{\mathrm{e}} v_{\mathrm{e}} \sigma_{\mathrm{i}}(E) f(E) d E
$$

(ガス分子密度 $n_{\mathrm{g}}$, 電子の速度 $v_{\mathrm{e}}$, イオン化断面積 $\left.\sigma_{\mathrm{i}}(E)\right)$ を用いて算出し, その空間分布を Fig. 3 に示し た.イオンはもっぱら誘電体との界面付近で発生し, 界 


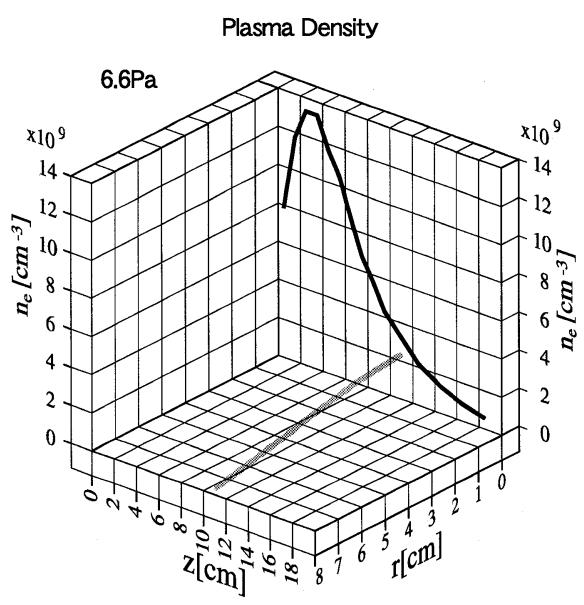

Fig. 2 Spatial distribution of the plasma density in nitrogen gas at $6.6 \mathrm{~Pa}$.

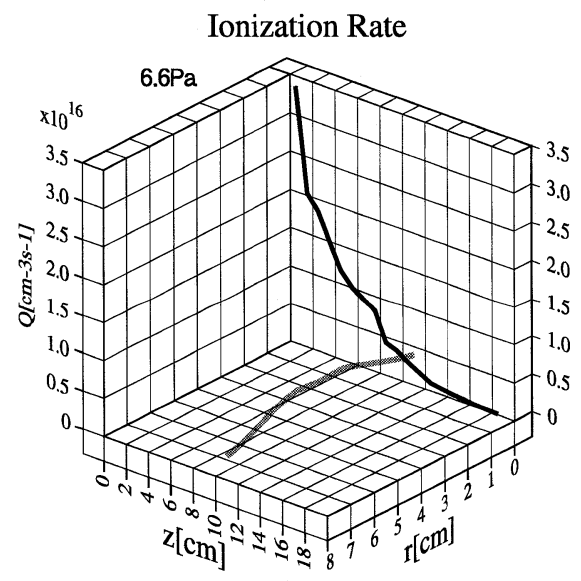

Fig. 3 Spatial distribution of the ionization rate.

面からの距離に指数関数的に減少している.

このイオン生成レートの分布 $Q(r, z)$ を元にプラズマ が古典的な両極性拡散則に従っているとすると, プラズ 又密度 $n_{\mathrm{e}}$ は, 両極性拡散定数を $D_{\mathrm{a}}$ として

$$
\frac{\partial n_{\mathrm{e}}}{\partial t}=D_{a} \nabla^{2} n_{\mathrm{e}}+Q
$$

と記述される. 容器壁面上でプラズマ密度が 0 になるこ とを境界条件とする，さらにQには $n_{\mathrm{e}}$ とエネルギー分 布関数の両方が(1)式のように入るため, 自己無撞着に は(2)式が解けなくなるが, Fig. 3 の結果にうまくフィ ッティングできる関数として

$$
Q(r, z)=Q_{0} J_{0}(\mathrm{kr}) \exp (-\gamma z),(k=0.267)
$$

と書けるものと仮定した. この定常解を求めて, $D_{\mathrm{a}}$ と Qとノをフィッティングパラメータとして, Fig. 2, Fig
3 にフィットさせることを試みたところ,$\gamma=0.7 \mathrm{~cm}^{-1}$, $Q_{0}=5 \times 10^{16} \mathrm{~cm}^{-3} \mathrm{~s}^{-1}, D_{\mathrm{a}}=2 \times 10^{6} \mathrm{~cm}^{-2} \mathrm{~s}^{-1}$ という值が求 められた．窒素分子などの中性粒子のこの圧力に抢ける 拡散定数 $D$ が $10^{4} \mathrm{~cm}^{2} \mathrm{~s}^{-1}$ のオーダーであり ${ }^{6)}, 2$ 桁大き い.この場合無磁場なので電子の移動度がイオンの移動 度に比べて充分大きい場合の両極性拡散定数の表式

$$
D_{\mathrm{a}} \approx D\left(1+T_{\mathrm{e}} / T_{\mathrm{i}}\right)
$$

が適用できる. 電子温度がイオン温度よりも 2 桁大きい ことは容易に考えられるので, 矛盾するものではない， またハイブリッド表面波モードの場合の電場のプラズマ への浸入長がちょうど $\gamma$ の逆数となり, 電場の遮蔽効果 を表わしている.

他方, イオン生成レートだけでなく, 分子の励起レー トや中性ラジカル生成レートも算出可能となる。ただし イオンの場合と異なり, 中性粒子の拡散は通常の D の 值の程度であるので, まさに $\gamma$ の逆数の程度の領域が関 わるだけで, 表面波モード励起を特徵づけている強い発 光が誘電体との界面付近に局在化することが説明でき る. よって表面波モードが生じている際には, 誘電体と の界面付近でプラズマ粒子が高いレートで生成され，プ ラズマの最大密度は界面ではなく, 両極性拡散により界 面から離れた位置で得られ, 電場は遮蔽される.つまり 界面付近で高効率にイオンと電子を生成することが本質 であり，それによってカットオフ密度を越えることが可 能となると考えられる.

次にマイクロ波電力を $300 \mathrm{~W}$ に保ち, アルゴンの流量 を $2 \mathrm{sccm}$ に設定し, 窒素ガスの流量を変化させて, 分 圧比を30：1から 1：1の範囲で変化させ, 発光スペク トル中の $\mathrm{Ar}, \mathrm{Ar}^{+}, \mathrm{N}_{2}^{+}, \mathrm{N}^{+}$（波長はそれぞれ420.1， 433.1，391.2，374.8 nm）の強度を測定した結果を Fig. 4 に示す．同図右軸では電子密度の値を表しており, 全圧 が約 2 倍変化しているにも関わらずプラズマ密度はほと んど一定である.これは表面波が離散的なモードしかな く，この場合もある一つのモードにロックしていたと理 解される.しかるに窒素の発光強度は窒素分圧に対して 連続的に増加している。これはモードロックを利用し て, ガスの混合比を選択することでラジカル密度やフラ ックス強度を自由に変化・設定させることが可能となる ことを示している．高周波放電や電子サイクロトロン共 鳴プラズマなどでは, 全圧, 混合比, 供給電力を独立に 設定しなけ机ばプラズマ密度, ラジカル密度を制御する ことができないので, 表面波プラズマの技術的利点の一 つとなる.

この実験で発光強度と同時に $\mathrm{z}=10 \mathrm{~cm}, \mathrm{r}=0 \mathrm{~cm}$ で測 定した電子エネルギー分布関数を窒素分圧をパラメータ にして Fig. 5 に示す。窒素分圧が高くなると $5 \mathrm{eV}$ 以上 


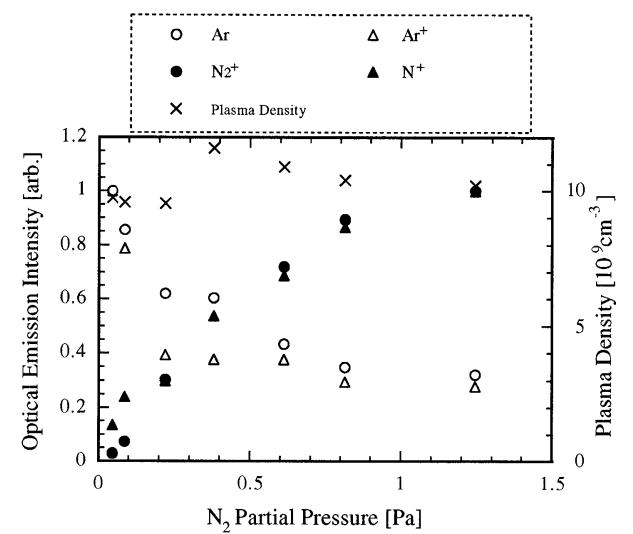

Fig. 4 Optical emission intensities from the plasma and the plasma density in $\mathrm{Ar}$ and $\mathrm{N}_{2}$ gas as functions of nitrogen partial pressure.

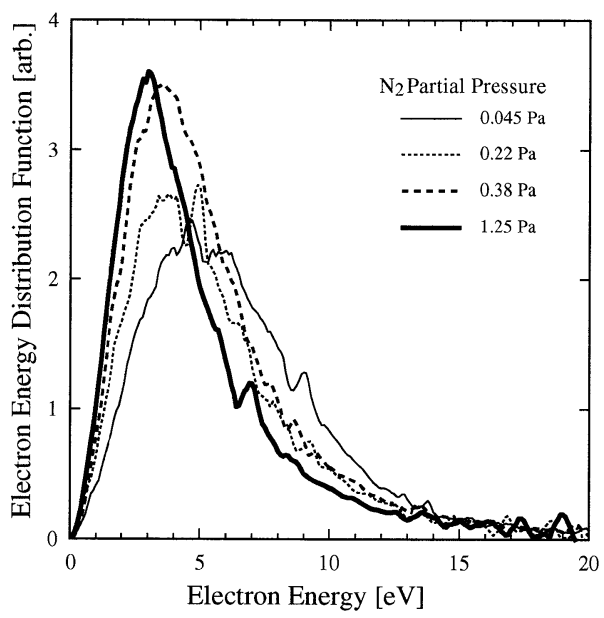

Fig. 5 Electron energy distribution function with the nitrogen partial pressure as a parameter.

の高エネルギー側の電子は減り，低エネルギ一側の電子 は増えている．この測定位置よりも誘電体側で高エネル ギーの電子が窒素の解離やイオン化に寄与してエネル ギーを失い，低エネルギーになって両極性拡散した結果
であると考えられる。

\section{4. 結 論}

超高真空対応のパイレクスヴューポートを活用し，リ ングスロット方式のマイクロ波ランチャーを用いてハイ ブリッドモード表面波による高密度プラズマを発生維持 できた，材料プロセシングのみならず，表面科学等で使 用される超高真空容器でも内部に電極を設けることなく プラズマを発生できることを示して打り，たとえば i situでシリコン表面の水素終端や，酸化被膜作成が可能 となるなどの応用も考えられよう．供給電力がまだ小さ いため，ハイブリッド表面波モードになる密度になって いた．プラズマから正味の電流を取り出さないプローブ 計測法を提唱し，そのプローブ計測で得られたプラズマ 密度の空間分布は, 誘電体との界面付近に局在分布する イオン生成が両極性拡散する結果と解釈された。またう ジカルを利用するプロセシングには，界面付近に基板等 をセットするか，界面から離れたところに於いてもまだ 充分高密度である電子を利用して，高周波バイアスなど を印可するなどの工夫が必要となろう.

\section{謝辞}

リングスロットランチャーの設計に際して東洋大学教 授岡本幸雄先生から多大な助言をいただいた。本研究は 文部科学省の科研費（13680552）の助成を得た。

\section{〔文献〕}

1) H. Sugai, I. Ghanashev and M. Nagatsu: Plasma Sources Sci. Technol., 7 (1998) 192.

2) M. Takahashi, M. Tsunoda and H. Shoji: Vacuum, 59 (2000) 814.

3) F. F. Chen: "Plasma Diagnostic Techniques" (R. H. Huddlestone and S. L. Leonard) (Academic, New York, 1965) Chap4.

4) T. Ohgushi, T. Okamoto, S. Watanabe and Y. Okamoto, Appl. Surf. Sci., 169-170 (2001) 593.

5) T. Banno, S. Michizono and Y. Saito: Appl. Surf. Sci., 169-170 (2001) 759.

6) A. Roth: "Vacuum Technology" (North-Holland, Amsterdam, 1976). 